Original Research Paper

\title{
Production and Quality in Dwarf Napier Grass Pasture Fertilized by Digested Effluent of Manure under Two-Years of Dairy Cow-Grazing in Warm Regions of Japan
}

\author{
${ }^{1}$ Hadijah Hasyim, ${ }^{2}$ Ahmad Wadi, ${ }^{3}$ Yasuyuki Ishii, ${ }^{3}$ Sachiko Idota and ${ }^{3}$ Kiichi Fukuyama \\ ${ }^{I}$ Interdisciplinary Graduate School of Agriculture and Engineering, University of Miyazaki, Miyazaki, Japan \\ ${ }^{2}$ Polytechnic Agriculture Negeri Pangkep, Segeri Mandalle, Indonesia \\ ${ }^{3}$ Faculty of Agriculture, University of Miyazaki, Miyazaki, Japan
}

Article history

Received: 09-02-2016

Revised: 09-03-2016

Accepted: 21-05-2016

Corresponsding Author:

Yasuyuki Ishii

Faculty of Agriculture,

University of Miyazaki,

Miyazaki, Japan

Email: yishii@cc.miyazaki-u.ac.jp

\begin{abstract}
Dwarf Napier grass (Pennisetum purpureum) pasture is suitable for beef cow grazing in warm regions of Japan, while it is not assessed for the suitability by a herd of dairy cows in the region. This study was conducted to determine the effects of Digested Effluent (DE) application on herbage yield and quality, Herbage Consumption (HC) and Dry Matter Intake (DMI) under a paddock scale of rotational grazing by a herd of dairy cows on dwarf Napier grass pasture in southern Kyushu, Japan for two years in 2007 and 2008. Plant growth attributes, such as plant height, tiller number and herbage mass and $\mathrm{HC}$ increased consistently from the first to the second or third grazing cycle in the two years. Pre-grazing herbage mass was averaged at 176 and $193 \mathrm{~g} \mathrm{~m}^{-2}$ in Chemical Fertilizer (CF) and DE treatments, respectively and HC and DMI did not differ between the two treatments. Overwintering ability was almost perfect in Miyazaki, judged by $97.1 \%$ of regrown plants in May 2008. Thus, dwarf Napier grass pasture fertilized with liquid DE can be utilized by dairy cow grazing as the same with CF fertilization, where DMI was averaged at $4.4 \mathrm{~kg}$ dry matter head $^{-1}$ day $^{-1}$ for 3 summer months in the two years.
\end{abstract}

Keywords: Digested Effluent of Manure, Dwarf Napier Grass, Quality, Rotational Grazing, Yield

\section{Introduction}

The impact of grazing animals on community structure and ecosystem functioning in the grass pasture is a key issue for rotational grazing management in order to maximize livestock production, sustainability and longevity of the pasture (Krysl and Hess, 1993). Grazing system is a management tool, which allows pasture managers to control the frequency and duration of grazing and rest periods to optimize livestock and plant performance (Savory and Parsons, 1980). One of the major factors, limiting milk production especially from a tropical pasture is a low Dry Matter Intake (DMI) by dairy cows (Distel et al., 1995), which is more intolerant to heat stress in a hot summer season in the warm region of Japan. It is important that Herbage Mass (HM) should be maintained throughout the grazing periods in order to achieve a high DMI, but changes in herbage quantity and quality associated with the huge consumption by grazing animals may have a serious damage on herbage DMI (McGilloway et al., 1999).

Dwarf variety of Late-heading type (DL) Napier grass (Pennisetum purpureum) bred in Florida, USA (Sollenberger et al., 1988), has already examined for the local adaptability in many tropics and subtropics of the world (Hanna et al., 1993; Williams and Hanna, 1995; Tudsri et al., 2002), as well as in the warm regions of Japan (Mukhtar et al., 2004; Utamy et al., 2011). Since southern Kyushu in the region has one of the largest beef cow densities in Japan, it is essential to treat livestock wastes promptly. One of the solution for processing livestock wastes is through the biogas-plant (Thy and Buntha, 2005), in which the end-product is the Digested Effluent of manure (DE) that could be applied to tropical grass pasture (Hasyim et al., 2014) at the same rate with annual fodder cropland. The DL Napier grass can adapt for the intensive rotational grazing by beef 
cows (Ishii et al., 2005) and is getting to expand cultivation areas in southern Kyushu (Utamy et al., 2011; Ishii et al., 2013). Grazed perennial DL Napier grass produces a high herbage mass and quality and hence provides herbages cheaper than imported hay feeding. The objectives of this study were to examine the effects of applying DE solution on herbage quantity, quality, consumption (HC) and DMI on DL Napier grass pasture by the rotational grazing of a herd of dairy cows in Miyazaki, southern Kyushu for 2 years in 2007 and 2008 .

\section{Materials and Methods}

\section{Site and Fertilizer Treatment}

The grazing study was carried out in Sumiyoshi Livestock Experimental Station (Sumiyoshi), University of Miyazaki, Japan $\left(131.46^{\circ} \mathrm{E}, 31.99^{\circ} \mathrm{N}\right)$ from 23 July 2007 to 31 October 2008. One-ha of DL Napier grass pasture, established by rooted tillers on 18-20 May 2005, was equally divided into 5 paddocks $(40 \times 50 \mathrm{~m}, 0.2 \mathrm{ha}$ each). Spacing and density of DL Napier grass were $1 \mathrm{~m}$ grid and 1 plant $\mathrm{m}^{-2}$, respectively. Each paddock was connected to the watering facility under shelter woods. For treatments, paddocks 1-3 were equally subdivided into 0.1 -ha areas with DE and Chemical Fertilizer (CF) plots and the other paddocks 4 and 5 were subjected to CF plot. DE plots were applied by liquid DE at $46 \mathrm{KL} \mathrm{ha}^{-1}$ year $^{-1}$ (112 kg of $\left.\mathrm{NH}_{4}^{+}-\mathrm{N}\right)$ by 4 times of split application in 2007 and at $58 \mathrm{KL} \mathrm{ha}^{-1}$ year $^{-1}\left(141 \mathrm{~kg}\right.$ of $\left.\mathrm{NH}_{4}^{+}-\mathrm{N}\right)$ by 5 times of split applications with additionally fertilized with chemical compound fertilizer at $93 \mathrm{~kg} \mathrm{~N} \mathrm{ha}^{-1}$ in 2008. CF plots were fertilized with $112 \mathrm{~kg} \mathrm{~N}$ and $234 \mathrm{~kg}$ $\mathrm{N} \mathrm{ha}^{-1}$ year $^{-1}$ of chemical compound fertilizer by 4 times and 5 times of split applications in 2007 and 2008, respectively. Overwintering ability was almost perfect in Miyazaki, judged by percentage of regrown plants at $97.1 \%$ in May 2008.

\section{Cut-and Carry Management}

Cut-and-carry study was conducted in Kibana Agricultural Experimental Station (Kibana), University of Miyazaki $\left(131.41^{\circ} \mathrm{E}, 31.83^{\circ} \mathrm{N}\right)$ in the same two years as reported in Heitschmidt et al. (1983). DL Napier grass was cultivated by transplanting rooted tillers at a rate of 2 plants $\mathrm{m}^{-2}(0.5 \times 1.0 \mathrm{~m}$ of spacing $)$ in 2007 and 2008 . Lime $\left(200 \mathrm{~g} \mathrm{~m}^{-2}\right)$ and fermented cattle manure (600 $\mathrm{g}$ $\mathrm{m}^{-2}$ ) were applied on 8 May 2007, as a basal dressing. Three DE treatments with a control fertilized with a CF as top dressing were employed with a randomized block design of three replications (blocks). DE treatments were supplied with 4-times of split application per year under three levels of application $\left(2.4,1.2\right.$ and $0.6 \mathrm{~L} \mathrm{~m}^{-2}$ per application equivalent to 5.04, 2.52 and $1.26 \mathrm{~g} \mathrm{~m}^{-2}$ nitrogen (N) per application, respectively), which constituted high, medium and low application rates, respectively. The control involved application of a $\mathrm{CF}$ at $36 \mathrm{~g} \mathrm{~m}^{-2}$ per application (5.04 $\mathrm{g} \mathrm{N} \mathrm{m}^{-2}$ per application), equivalent to the high rate of $\mathrm{N}$ application in $\mathrm{DE}$ treatment on the same days. At Kibana, the cutting height of DL Napier grass was simulated with the grazing trial in Sumiyoshi, where the defoliated stubble height was risen with grazing proceeded.

\section{Grazing Management}

A herd of lactating dairy cows (Holstein, 23 head and initial body weight averaged at $552 \mathrm{~kg}$ ), which was almost half of the average daily farms (41.7 head) in Miyazaki (MAFF, 2011), were used for the rotational grazing on one-ha DL Napier grass pasture. Grazing schedule was totally 4 cycles both in 2007 and 2008, where the first 3 cycles were from 23 July to 30 October and from 14 July to 22 October in 2007 and 2008 , respectively with 5 days of grazing and almost 4 weeks of rest period for each paddock. The fourth cycle was from 5 to 22 November and from 27 to 31 October in 2007 and 2008, respectively, since the grazing period in the last fourth cycle was according to the pre-grazing herbage mass due to the decline in air temperature in the rest period after the third grazing was terminated. Three-six days of rest period folded at the switching grazing cycle.

\section{Plant Measurements for Herbage Yield,} Consumption and Dry Matter Intake by Dairy Cows

Ten DL Napier grass plants per paddocks were sampled by line transecting method at both pre- and post-grazing in each paddock. Both pre- and postgrazing Dry Matter Weights (DMWs) of herbages were determined by cutting plants at $10 \mathrm{~cm}$ above the ground level. Measured plant characters were tiller number, plant height and DMWs of Leaf Blade (LB), stem inclusive of with leaf Sheath (ST) and Dead parts (D). Both pre- and post-grazing plant height and pre-grazing tiller number were determined at four fixed rows (40 plants) per paddock.

Amount of herbage production in the grazing period was calculated by estimated Crop Growth Rate (CGR), multiplied by the grazing days. The HC by dairy cows was determined by the sum of the difference between pre- and post-grazing herbage mass and herbage production in the grazing days. The DMI by dairy cows was calculated by $\mathrm{HC}$, multiplied by plant area, divided by number of grazing cows and grazing day.

\section{Chemical Analysis for Forage Quality and Liquid DE}

In vitro Dry Matter Digestibility (IVDMD) of herbage was determined by pepsin-cellulase digestion 
assay using in vitro incubator (Model: DAISY II200/220, ANKOM Technology Co. Ltd., Macedon, NY, USA) regulated at $39.0^{\circ} \mathrm{C}$. Neutral detergent fiber (NDF), Acid Detergent Fiber (ADF) and Acid Detergent Lignin (ADL) contents of herbages were determined by detergent assay method using fiber analyzer (Model: ANKOM 200/220, ANKOM Technology Co. Ltd., Macedon, NY, USA). The major mineral ion content of liquid DE was determined by Ion-analyzer (Model: IA-300, Toa-DKK Co. Ltd., Tokyo, Japan).

\section{Statistical Analysis}

For plant attributes, consumption and intake of herbages of DL Napier grass, one-way Analysis of Variance (ANOVA) for a completely randomized design was performed using SPSS software (version 15.0, Madison, USA). Mean separations were tested using the Least Significance Difference (LSD) method at the $1 \%$ and $5 \%$ level.

\section{Results}

\section{Plant Growth Attributes in the Grazing Period}

Changes in both pre- and post-grazing plant height of DL Napier grass pasture over time are shown across paddocks for 2007 (A) and 2008 (B) in Fig. 1. Pregrazing plant height increased up to cycle 2 or 3 and decreased through to cycle 4 and tended to be higher in paddock 5 than in the other paddocks across cycles for both years and tended to be higher in 2008 than in 2007. However, post-grazing plant height remained similarly across paddocks around $40-50 \mathrm{~cm}$ above the ground, where lamina junction was positioned. No significant effects on pre- or post-grazing plant height were obtained by DE application, compared with CF treatment (Fig. 1).

Pre- and post-grazing tiller densities of DL Napier grass pasture increased consistently from the first to the last cycle and tended to be larger by DE application than $\mathrm{CF}$ treatment over grazing cycles in the two years and tended to be larger in 2008 (B) than in 2007 (A) in Fig. 2. No significant effects on pre- or post-grazing tiller density were obtained by DE application, compared with CF treatment over the two years. Increase in tiller density with grazing cycles suggested for high tillering ability of mother tillers after defoliation by the grazing of dairy cows.

Pre- and post-grazing herbage mass of DL Napier grass pasture increased consistently from the first cycle to the third cycle in the two years (Fig. 3). Pre-grazing herbage masses averaged across 4 cycles for $\mathrm{CF}$ and $\mathrm{DE}$ treatment, respectively, were 165 and $161 \mathrm{~g} \mathrm{~m}^{-2}$ in 2007 and 187 and $224 \mathrm{~g} \mathrm{~m}^{-2}$ in 2008, while no significant difference was obtained between the two treatments. The variation in pre-grazing herbage mass was almost correlated with that in tiller density within cycles 1 to 3 in $2007(\mathrm{r}=0.517, \mathrm{p}<0.01)$ and in $2008(\mathrm{r}=0.643$, $\mathrm{p}<0.01)$. The increase in herbage mass was concurrent with that in tiller density up to cycle 3 , while regrowth in herbage mass suppressed severely in the rest period after the third cycle in the two years. Rotational grazing showed that pre-grazing plant characters in plant height, tiller density and herbage mass showed large variations among paddocks, while the postgrazing characters were more stable than the pregrazing ones over the two years.

Pre- and post-grazing percentage of leaf blade (PLB) in DL Napier grass decreased consistently from the first cycle to the last cycle in the two years and tended to be higher in 2008 than in 2007. Pre-grazing PLB was extremely high, while the post-grazing percentage decreased significantly due to the consumption of dairy cows grazed mostly at the lamina junction of shoots. New tillers emerging from the elongated stem nodes were favorable for the quick coverage of land by leafage, compared with those only from the underground stem nodes. The postgrazing PLB tended to be higher in DE treatment than in $\mathrm{CF}$ treatment and decreased constantly to around $20 \%$ in the third cycle of the two years (Fig. 4).

\section{Herbage Consumption and Dry Matter Intake}

Herbage consumption increased from the first cycle to the third cycle and turned to drop severely at the last paddock 1 or 4 in CF treatment in the two years. The DMI by dairy cows increased from the first to the third cycle and was closely correlated with $\mathrm{HC}$, from the first to the third cycle. The DMIs in CF and DE treatment averaged across 4 cycles were 4.1 and $7.0 \mathrm{~kg}$ Dry Matter (DM) head ${ }^{-1}$ day $^{-1}$, respectively, in 2007 and 2.8 and $3.6 \mathrm{~kg} \mathrm{DM}$ head $^{-1} \mathrm{day}^{-1}$, respectively, in 2008 (Table 2). The rise of DMI in paddocks 1-3 at the last cycle in 2007 was brought about by the only one-day of grazing practice due to poor regrowth and shortage in herbage (Fig. 5).

\section{Herbage Quality}

Changes in pre-grazing IVDMD of DL Napier grass pasture showed in Fig. 6 that IVDMD was the highest in cycle 1 and 2 in 2007 and 2008, respectively and decreased constantly over time in the two years, while IVDMD even at the fourth cycle maintained above 55 and $60 \%$ in 2007 and 2008, respectively. In the first cycle of the two years, IVDMD tended to be higher in ST than in LB, although no significant differences were obtained between the two fractions across cycles (Fig. 6). 


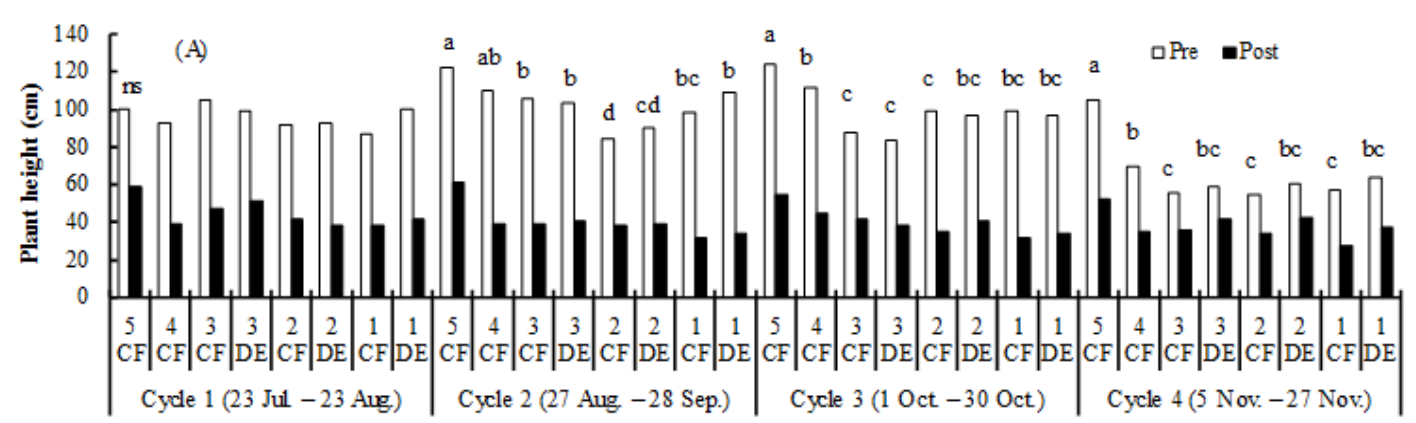

Cycle, paddock and treatment

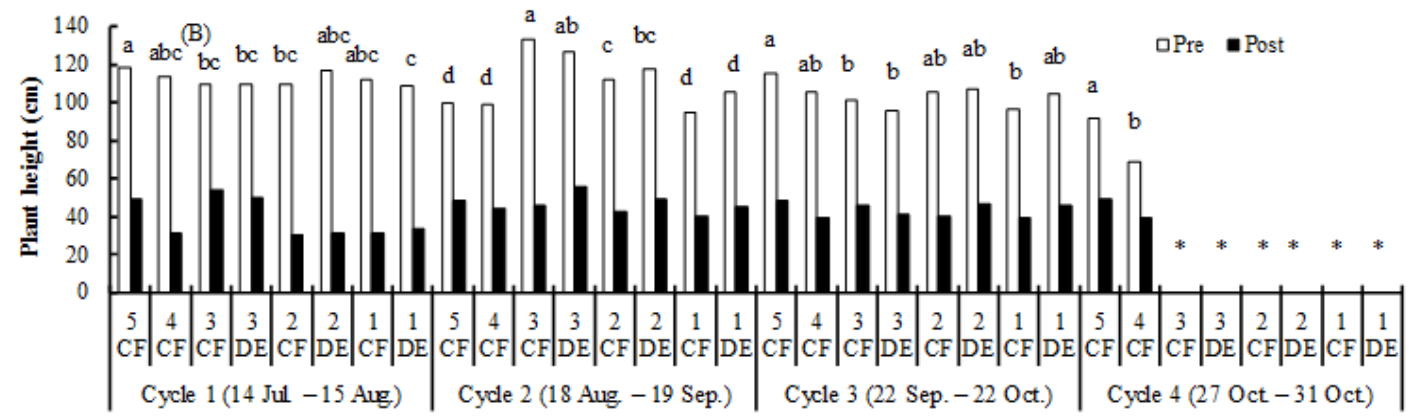

Cycle, paddock and treatment

Fig. 1. Changes in pre- and post-grazing plant height in the dwarf Napier grass pasture in 2007 (A) and 2008 (B). * Not conducted. Treatment: Chemical Compound Fertilizer (CF), Digested Effluent of manure (DE). Symbols with different letters denote significant difference among pre-grazing paddocks and treatments in the same cycle at the $5 \%$ level. ns: $p>0.05$.

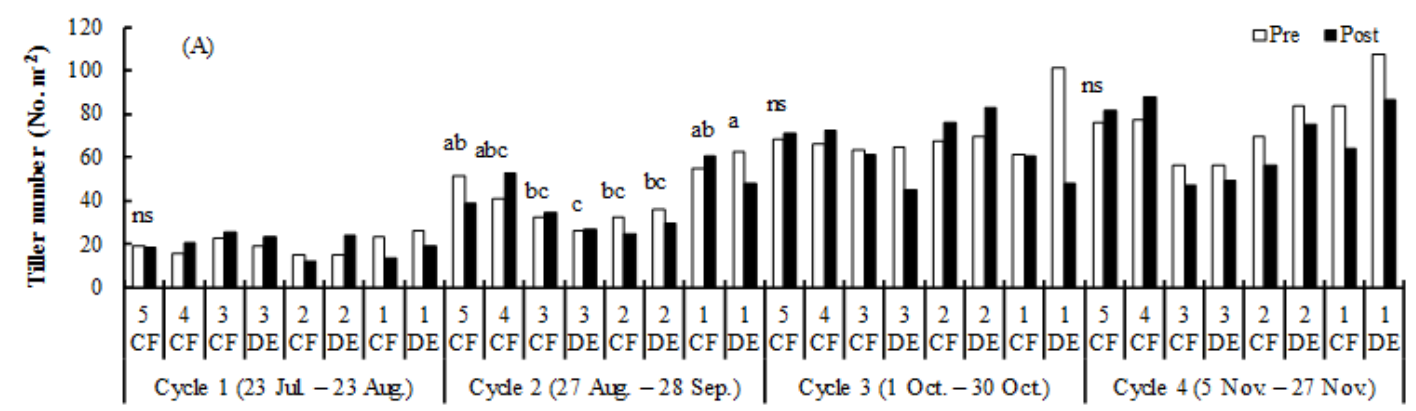

Cycle, paddock and treatment

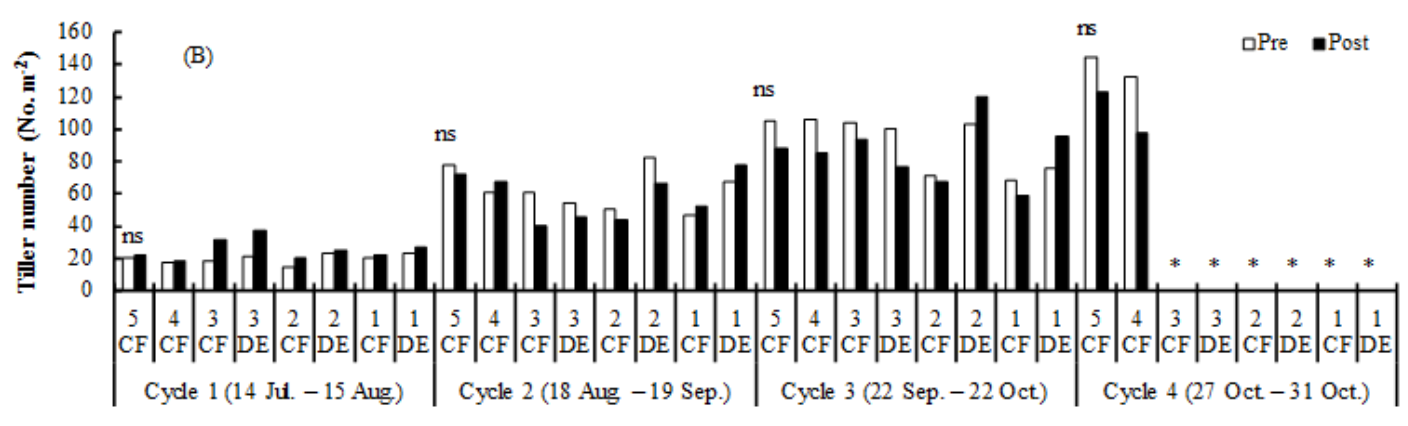

Cycle, paddock and treatment

Fig. 2. Changes in pre- and post-grazing tiller number over time in the dwarf Napier grass pasture in 2007 (A) and 2008 (B). * Not conducted. Treatment: Chemical Compound Fertilizer (CF), Digested Effluent of manure (DE). Symbols with different letters denote significant difference among pre-grazing paddocks and treatments in the same cycle at the 5\% level. ns: $p>0.05$ 


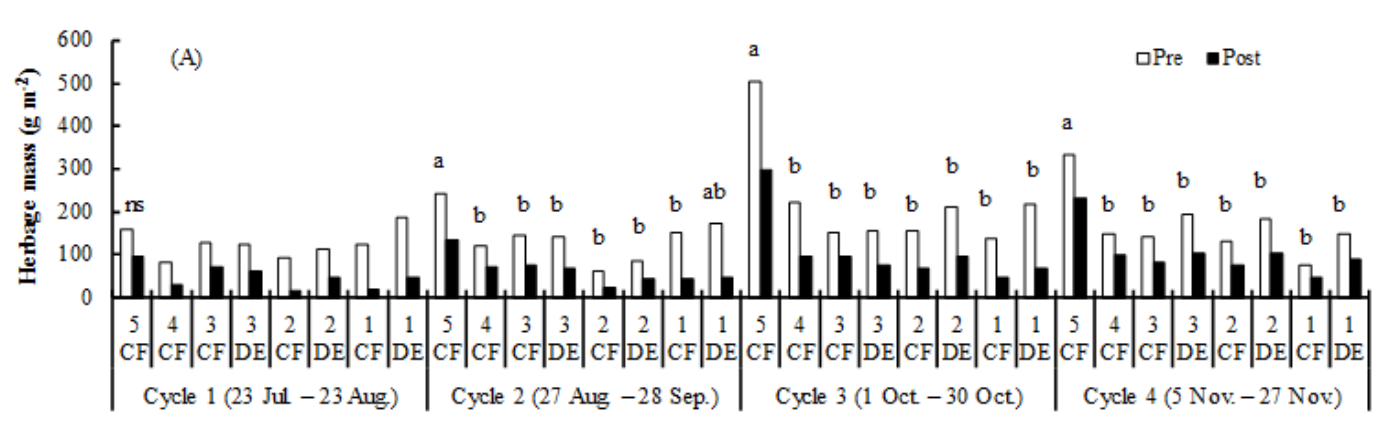

Cycle, paddock and tre atment

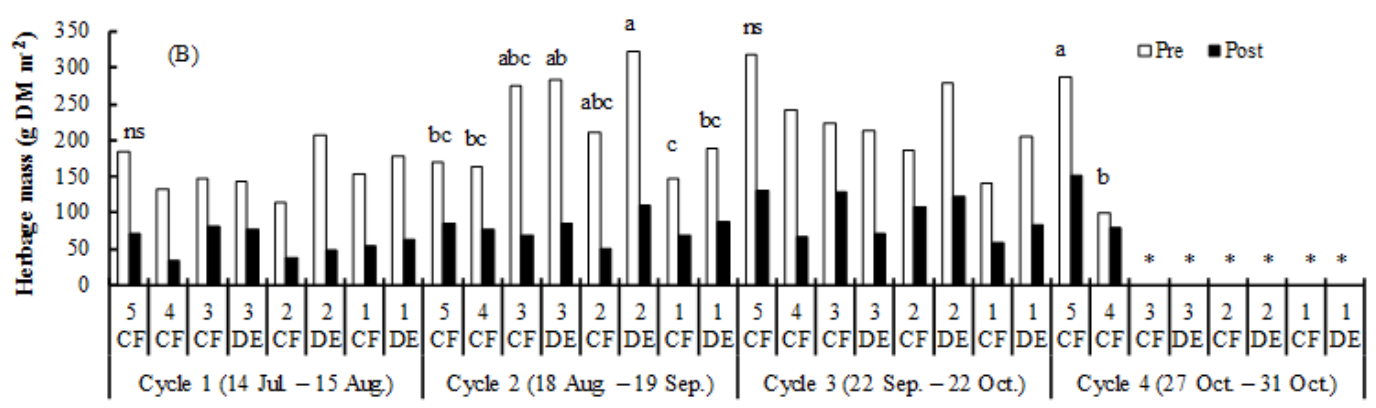

Cycle, paddock and treatment

Fig. 3. Changes in pre- and post-grazing herbage mass over time in the dwarf Napier grass pasture in 2007 (A) and 2008 (B). * Not conducted. Treatment: Chemical compound Fertilizer (CF), Digested Effluent of manure (DE). Symbols with different letters denote significant difference among pre-grazing paddocks and treatments in the same cycle at the 5\% level. ns: $\mathrm{p}>0.05$
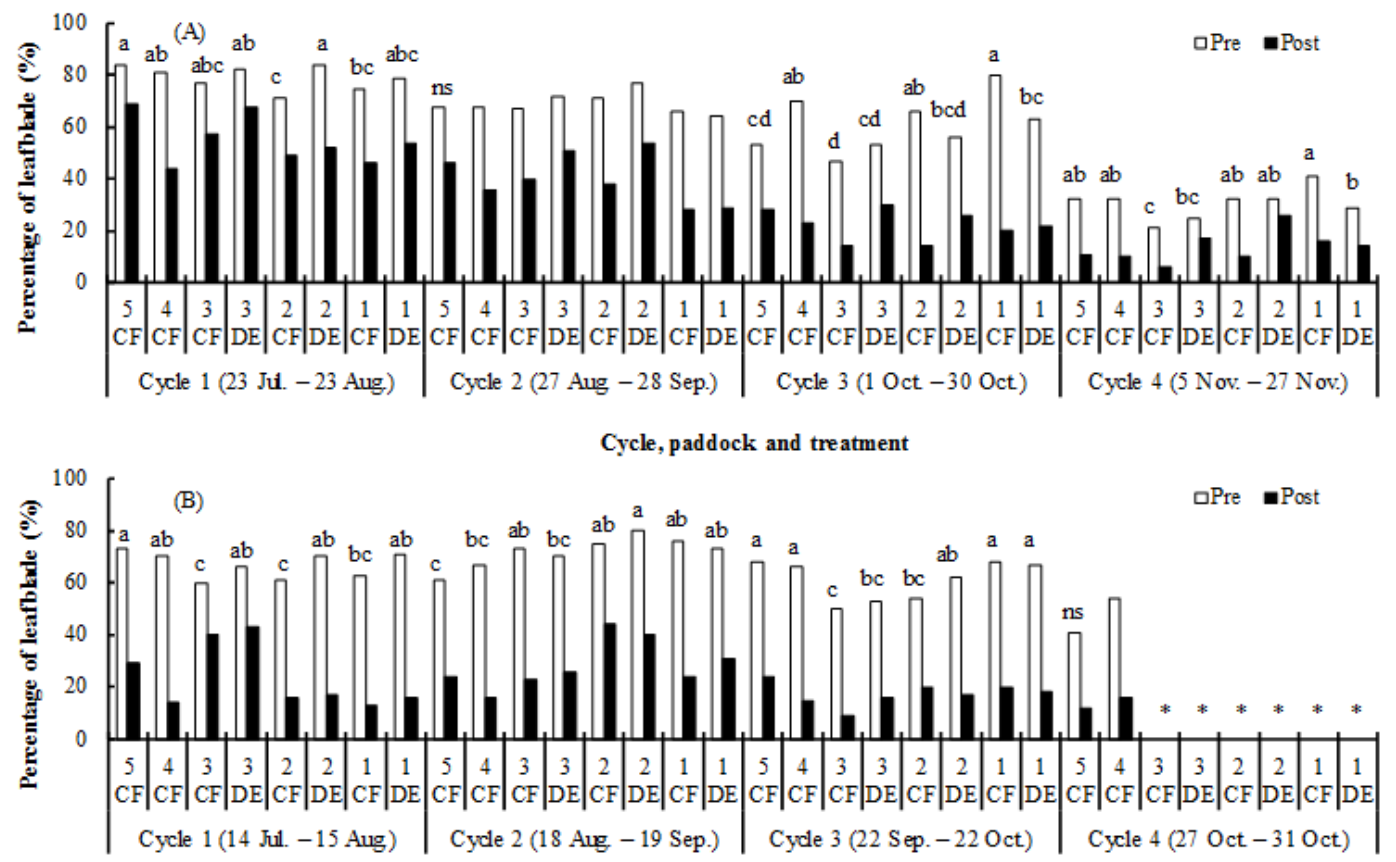

Cycle, paddock and treatment

Fig. 4. Changes in pre- and post-grazing percentage of leaf blade over time in the dwarf Napier grass pasture in 2007 (A) and 2008 (B). * Not conducted. Treatment: Chemical compound Fertilizer (CF), Digested Effluent of manure (DE). Symbols with different letters denote significant difference among pre-grazing paddocks and treatments in the same cycle at the $5 \%$ level. ns: $\mathrm{p}>0.05$ 


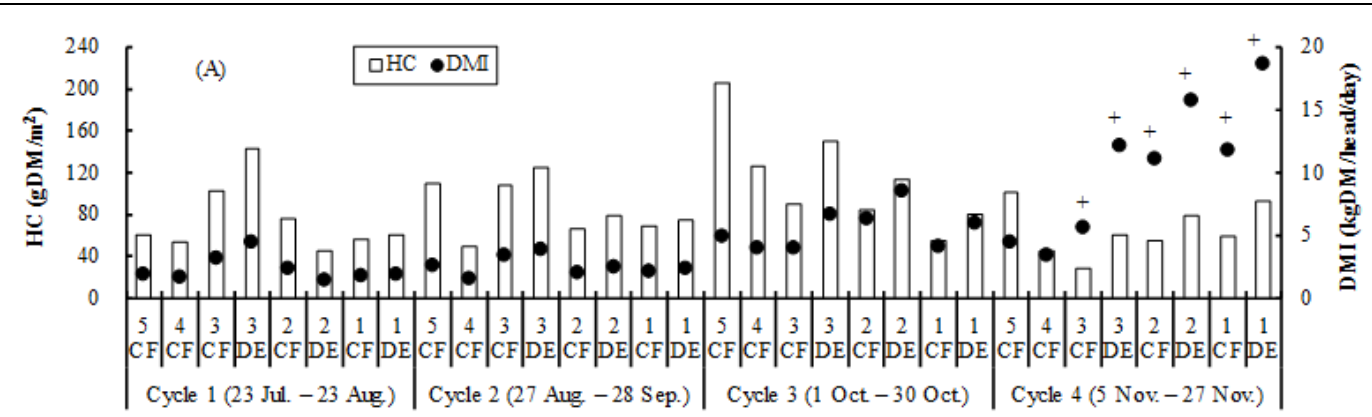

Cycle, paddock and treatment

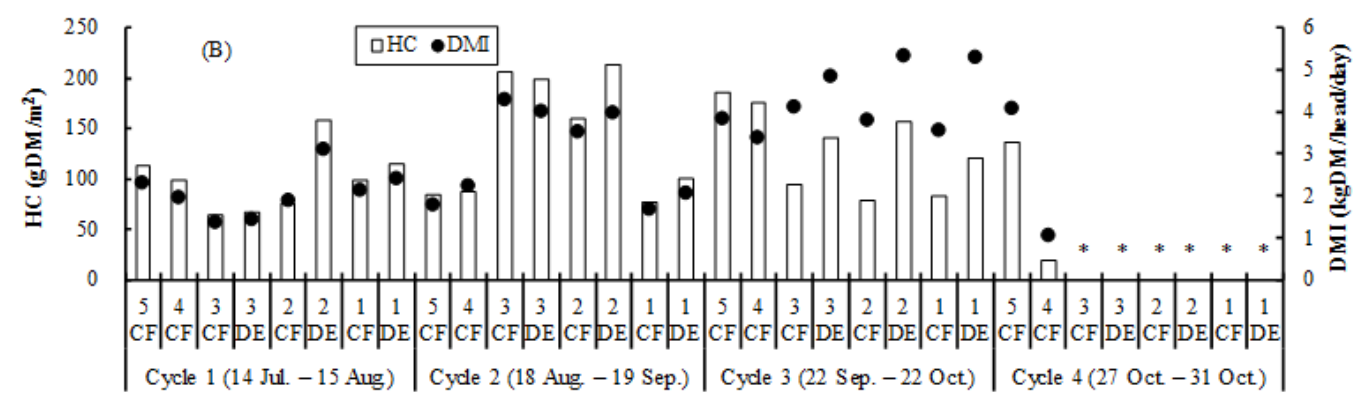

Cycle, paddock and treatment

Fig. 5. Changes in the Herbage Consumption (HC) and Dry Matter Intake (DMI) over time in the dwarf Napier grass pasture in 2007 (A) and 2008 (B). *Not conducted. Treatment: Chemical compound Fertilizer (CF), Digested Effluent of manure (DE). Symbols with different letters denote significant difference among pre-grazing paddocks and treatments in the same cycle at the $5 \%$ level. ns: $p>0.05$

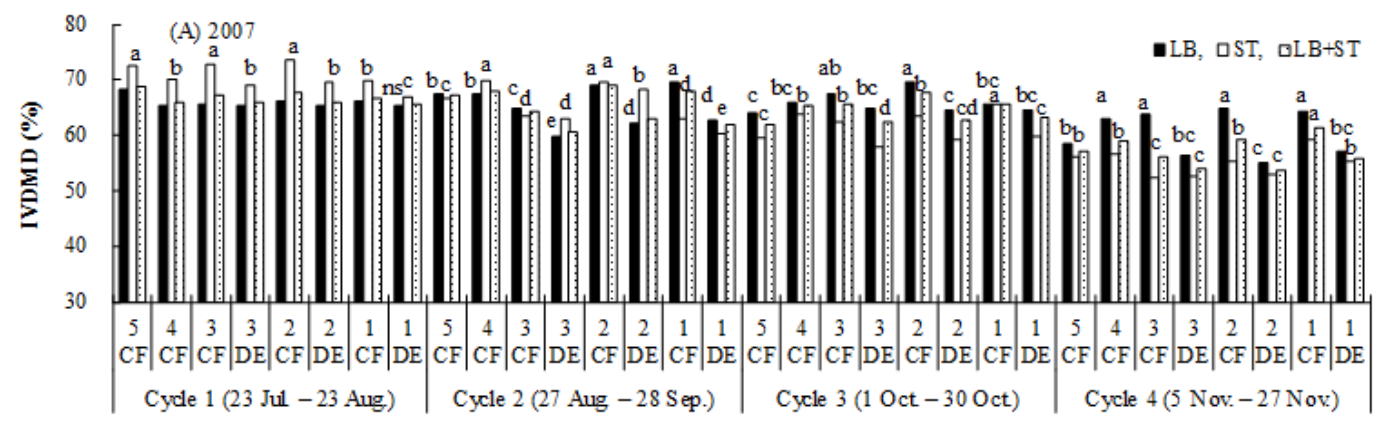

Cycle, paddock and treatment

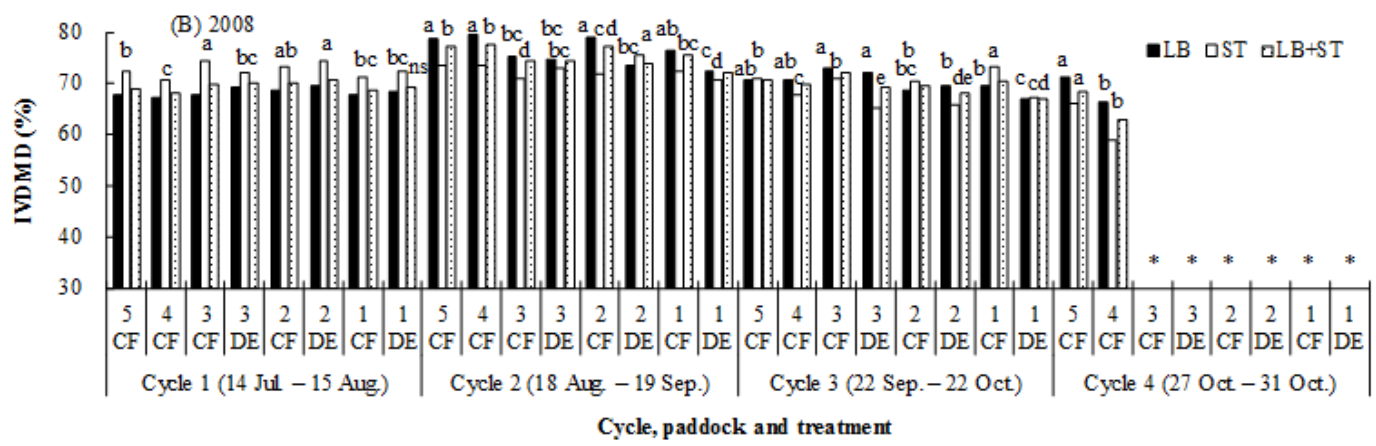

Fig. 6. Changes in the pre-grazing In Vitro Dry Matter Digestibility (IVDMD) of dwarf Napier grass over time in 2007 (A) and 2008 (B). *Not conducted. Treatment: Chemical compound Fertilizer (CF), Digested Effluent of manure (DE). LB: Leaf blade, ST: stem inclusive of leaf sheath. * Not conducted. Symbols with different letters denote significant difference among pre-grazing paddocks and treatments in the same cycle at the 5\% level. ns: $p>0.05$ 
Table 1. Changes in Neutral Detergent Fiber (NDF), Acid Detergent Fiber (ADF) and Acid Detergent Lignin (ADL) contents in Leaf Blade (LB) and stem inclusive of leaf sheath (ST) over time in 2007 and 2008

\begin{tabular}{|c|c|c|c|c|c|c|c|c|}
\hline \multirow[b]{2}{*}{ Year } & \multirow[b]{2}{*}{ Cycle and period } & \multirow[b]{2}{*}{ Organ $^{\dagger}$} & \multicolumn{2}{|c|}{ NDF (\%DM) } & \multicolumn{2}{|c|}{ ADF (\%DM) } & \multicolumn{2}{|c|}{ ADL (\%DM) } \\
\hline & & & $\mathrm{CF}^{\dagger \dagger}$ & $\mathrm{DE}^{\dagger \dagger}$ & $\mathrm{CF}$ & $\mathrm{DE}$ & $\mathrm{CF}$ & $\mathrm{DE}$ \\
\hline \multirow[t]{8}{*}{2007} & I (23 Jul.-23 Aug.) & LB & $63.8 \mathrm{~ns}^{\dagger \dagger \dagger}$ & 64.4 & $35.0^{\mathrm{b}}$ & $36.7^{\mathrm{a}}$ & $5.4^{\mathrm{b}}$ & $6.9^{\mathrm{a}}$ \\
\hline & & ST & $60.1 \mathrm{~ns}$ & 61.0 & $35.0 \mathrm{~ns}$ & 35.9 & $5.4 \mathrm{~ns}$ & 5.9 \\
\hline & II (27 Aug.-28 Sep.) & LB & $65.3 \mathrm{~ns}$ & 64.6 & $35.2^{\mathrm{b}}$ & $38.4^{\mathrm{a}}$ & $5.3^{\mathrm{b}}$ & $7.1^{\mathrm{a}}$ \\
\hline & & $\mathrm{ST}$ & $63.9^{\mathrm{b}}$ & $66.0^{\mathrm{a}}$ & $37.3 \mathrm{~ns}$ & 38.3 & $5.2^{\mathrm{b}}$ & $6.9^{\mathrm{a}}$ \\
\hline & III (1 Oct.-30 Oct.) & LB & $65.5 \mathrm{~ns}$ & 65.7 & $35.7^{\mathrm{b}}$ & $38.1^{\mathrm{a}}$ & $5.1^{b}$ & $7.2^{\mathrm{a}}$ \\
\hline & & ST & $62.8^{\mathrm{b}}$ & $64.9^{\mathrm{a}}$ & $37.5^{\mathrm{b}}$ & $39.3^{\mathrm{a}}$ & $5.9^{\mathrm{b}}$ & $6.9^{\mathrm{a}}$ \\
\hline & IV (5 Nov.-27 Nov.) & LB & $63.3^{\mathrm{a}}$ & $60.9^{\mathrm{b}}$ & $37.2^{\mathrm{b}}$ & $38.6^{\mathrm{a}}$ & $7.0^{\mathrm{b}}$ & $7.8^{\mathrm{a}}$ \\
\hline & & ST & $63.4^{\mathrm{b}}$ & $64.7^{\mathrm{a}}$ & $39.7 \mathrm{~ns}$ & 39.6 & $6.3^{\mathrm{b}}$ & $7.7^{\mathrm{a}}$ \\
\hline \multirow[t]{8}{*}{2008} & I (14 Jul.-15 Aug.) & LB & $64.9^{\mathrm{a}}$ & $62.6^{\mathrm{b}}$ & $37.1^{\mathrm{b}}$ & $38.8^{\mathrm{a}}$ & $6.0 \mathrm{~ns}$ & 6.5 \\
\hline & & ST & $58.9 \mathrm{~ns}$ & 58.9 & $34.9^{\mathrm{b}}$ & $36.2^{\mathrm{a}}$ & $5.2 \mathrm{~ns}$ & 5.7 \\
\hline & II (18 Aug.-19 Sep.) & LB & $60.7 \mathrm{~ns}$ & 61.4 & $35.2^{\mathrm{b}}$ & $37.3^{\mathrm{a}}$ & $6.2 \mathrm{~ns}$ & 6.7 \\
\hline & & ST & $59.8 \mathrm{~ns}$ & 59.9 & $38.0 \mathrm{~ns}$ & 37.0 & $5.4^{\mathrm{b}}$ & $6.3^{\mathrm{a}}$ \\
\hline & III (22 Sep.-22 Oct.) & LB & $60.1^{\mathrm{b}}$ & $61.7^{\mathrm{a}}$ & $35.1 \mathrm{~ns}$ & 35.9 & $5.8^{\mathrm{b}}$ & $7.2^{\mathrm{a}}$ \\
\hline & & ST & $58.4 \mathrm{~ns}$ & 58.7 & $36.6^{\mathrm{b}}$ & $38.5^{\mathrm{a}}$ & $5.2-$ & $6.0^{\mathrm{a}}$ \\
\hline & IV (27 Oct.-31 Oct.) & LB & 63.5 & - & 34.5 & - & 7.7 & - \\
\hline & & ST & 63.1 & - & 37.9 & - & 7.3 & - \\
\hline
\end{tabular}

$\bar{\dagger}$ Organ: LB (Leaf Blade), ST (stem inclusive of leaf sheath); ${ }^{\dagger}$ Treatment: CF (Chemical Fertilizer), DE (Digested Effluent of manure); ${ }^{\dagger \dagger}$ Symbols with different letters in a row denote significant difference for NDF, ADF and ADL among treatments on the same cycle at the $5 \%$ level. ns: Non-significant $(\mathrm{p}>0.05)$.

Table 2. Effect of fertilizing source on pre-grazing herbage mass, quality and consumption and dry matter intake in the 2 years of 2007 and 2008

\begin{tabular}{|c|c|c|c|c|}
\hline \multirow[b]{2}{*}{ Year } & \multirow[b]{2}{*}{ Character } & \multicolumn{2}{|c|}{ Treatment $^{\dagger}$} & \multirow[b]{2}{*}{ Significance } \\
\hline & & $\mathrm{CF}$ & $\mathrm{DE}$ & \\
\hline \multirow[t]{7}{*}{2007} & Herbage mass $\left(\mathrm{g} \mathrm{DM} \mathrm{m}^{-2}\right)$ & 164.90 & 161.10 & $\mathrm{p}>0.05$ \\
\hline & Herbage IVDMD (\%) & 64.60 & 61.20 & $\mathrm{p}<0.05$ \\
\hline & Herbage NDF content (\%) & 64.00 & 64.40 & $\mathrm{p}>0.05$ \\
\hline & Herbage ADF content (\%) & 36.50 & 38.20 & $\mathrm{p}<0.01$ \\
\hline & Herbage ADL content $(\%)$ & 5.66 & 7.17 & $\mathrm{p}<0.01$ \\
\hline & Herbage consumption $\left(\mathrm{g} \mathrm{DM} \mathrm{m}^{-2}\right)$ & 80.30 & 92.00 & $\mathrm{p}>0.05$ \\
\hline & Dry matter intake $\left(\mathrm{g} \mathrm{DM}\right.$ head $^{-1}$ day $\left.^{-1}\right)$ & 4.10 & 7.00 & $\mathrm{p}>0.05$ \\
\hline \multirow[t]{7}{*}{2008} & Herbage mass $\left(\mathrm{g} \mathrm{DM} \mathrm{m}^{-2}\right)$ & 188.00 & 224.10 & $\mathrm{p}>0.05$ \\
\hline & Herbage IVDMD (\%) & 71.20 & 70.50 & $\mathrm{p}>0.05$ \\
\hline & Herbage NDF content $(\%)$ & 61.40 & 61.20 & $\mathrm{p}>0.05$ \\
\hline & Herbage ADF content (\%) & 36.00 & 37.40 & $\mathrm{p}<0.01$ \\
\hline & Herbage ADL content $(\%)$ & 5.98 & 6.57 & $\mathrm{p}<0.05$ \\
\hline & Herbage consumption $\left(\mathrm{g} \mathrm{DM} \mathrm{m}^{-2}\right)$ & 108.40 & 141.10 & $\mathrm{p}>0.05$ \\
\hline & Dry matter intake $\left(\mathrm{g}\right.$ DM head ${ }^{-1}$ day $\left.^{-1}\right)$ & 2.80 & 3.60 & $\mathrm{p}>0.05$ \\
\hline
\end{tabular}

Treatment: Chemical Fertilizer (CF), Digested Effluent of manure (DE).

Changes in NDF, ADF and ADL contents in LB and ST of the same plant samples over time are shown in Table 1. NDF contents in CF and DE treatments averaged 63.5 and $64.0 \%$, respectively in 2007 and 61.2 and $60.5 \%$, respectively in 2008. ADF contents in $\mathrm{CF}$ and DE treatments averaged 36.6 and $38.1 \%$, respectively in 2007 and 36.1 and $37.3 \%$, respectively in 2008. ADL contents in CF and DE treatments averaged 5.7 and $7.1 \%$, respectively in 2007 and 6.1 and $6.4 \%$, respectively in 2008. NDF content did not differ consistently between CF and DE treatment across cycles, while $\mathrm{ADF}$ and $\mathrm{ADL}$ contents tended to be higher in $\mathrm{DE}$ treatment than in CF treatment, although the difference was not statistically significant.

In ST, correlations of IVDMD with NDF, ADF and ADL contents were $r=-0.568(p<0.05),-0.841(p<0.01)$ and $-0.913(\mathrm{p}<0.01)$, respectively under DE treatment in 2007, while the significantly positive correlation $(\mathrm{r}=$ $0.817, \mathrm{p}<0.01$ ) of IVDMD with NDF content was obtained in LB under DE treatment in 2007. CF 
treatment also caused negative correlations of IVDMD with the three fiber fractions in ST $(r=-0.614,-0.904$, $0.751)$, which were significant at the $1 \%$ level.

\section{Discussion}

\section{Response of Plant Characters, Herbage Consumption and Intake by Grazing Animals to Different Source of Fertilizer Application}

Effect of fertilizing sources, CF and DE on plant growth attributes, herbage consumption and intake by grazing animals are summarized in Table 2. No significant differences obtained in every attribute between the two fertilizing sources, except for the pregrazing herbage IVDMD in 2007 and ADF and ADL content in 2007 and 2008. Higher IVDMD in CF treatment was concurrent with lower ADF and ADL contents than in DE treatment and these quality attributes were closely related with herbage mass (Minson, 1990). In our previous research on herbage yield and quality in DL Napier grass pasture supplied by the two fertilizing sources, positive correlation of herbage yield with fiber contents and negative correlation of that with IVDMD were obtained (Hasyim et al., 2010). Except for these minor variations between the two fertilizing sources, the effect of DE application on herbage mass and consumption was almost equivalent with that of $\mathrm{CF}$ application in DL Napier grass pasture for 2 years of grazing practice.

\section{Variations in Plant Response to DE Application between Cut-and-Carry and Grazing Systems}

The effect of DE application on herbage yield under the dairy-cow grazing was almost equivalent with that of $\mathrm{CF}$ application in the two years. Responses of herbage production to DE application can be compared with our previous results in the cut-and-carry system, where the cutting height was simulated with the defoliated height by the current grazing trials and $\mathrm{DE}$ was applied at 3 levels, combined with the highest $\mathrm{N}$ level of DE by $\mathrm{CF}$ application in the same two years (Hasyim et al., 2014). A sole positive correlation was obtained in each year between herbage mass and $\mathrm{N}$ input in the annual total across cutting and grazing systems under both $\mathrm{DE}$ and CF applications (Fig. 7). The regression coefficient was almost the same at around $19 \mathrm{~g} \mathrm{DM} \mathrm{g} \mathrm{N}^{-1}$ between the two years, while y-intercept increased from 2007 to 2008 possibly due to several reasons. The first reason for increasing herbage yield could be doubling $\mathrm{N}$ input from 11.2 in 2007 to $23.4 \mathrm{~g} \mathrm{~N} \mathrm{~m}^{-2} \mathrm{yr}^{-1}$ in 2008 at the present grazing study and the second reason might be due to the regrowth from the overwintered stubbles in 2008. It is a common feature for Napier grass that annual herbage yield increased in the following year after establishment
(Wadi et al., 2004). Therefore, it is concluded that effect of DE application on stimulating herbage production was regulated by the rate of $\mathrm{N}$ input in the same regression with $\mathrm{CF}$ application.

\section{Handling Difficulty of Spraying Liquid DE to the Grazing Pasture}

In the present study, liquid DE was applied to DL Napier grass pasture twice before the grazing started on DL Napier grass pasture and at every cycle after the grazing terminated in each paddock. Therefore, almost $1,200 \mathrm{~L}\left(1.2 \mathrm{~m}^{3}\right)$ of liquid DE needed to be transported from the bio-gas plant to 0.2 -ha of post-grazing pasture and be applied by vacuumed sprayer. However, this fertilization method has several merits that DL Napier grass pasture required high rate of liquid $\mathrm{DE}$ at more than $200 \mathrm{~kg} \mathrm{~N} \mathrm{ha}^{-1} \mathrm{yr}^{-1}$ in the growing season, which was a suitable situation for high density of livestock producers in southern Kyushu and pasture managers can replace purchase of chemical fertilizer with the application of liquid DE to reduce the fertilization cost. It is necessary to estimate the effect of supplying liquid $\mathrm{DE}$ on the quality in soil and percolated water (Hasyim et al., 2009).

Effect of Spraying Liquid DE to Leafage of DL Napier Grass on Herbage Consumption by Grazing Animals

It is a common feature that positions of cattle dung on the grazing pasture interfere with the grazing behaviors of animals (Marten and Donker, 1964; Marsh and Campling, 1970). Even if liquid DE had already fermented in an anaerobic process by bio-gas plant ( $\mathrm{Cu}$ et al., 2015), there remained slight odor in the solution. In the present study, we maintained almost 30 days of rest period after foliar application of liquid DE was carried out at the post-grazing in each paddock and herbage consumption was not significantly different between DE and CF plot in either year. We had a preliminary trial where restart of grazing by dairy cows was conducted just after the foliar application of liquid DE was completed at the post-grazed DL Napier grass pasture as usual, to find that grazing behavior of dairy cows had no obvious difference between DE-applied and $\mathrm{CF}$ areas. Therefore, it is suggested that soil injection or percolation by fertilizing tube should not be necessary for supplying liquid DE instead of foliar application, which is much more convenient method of liquid fertilizer (Schröder et al., 2005). Liquid fertilizer in a foliar application seemed to be fast effective than the solid fertilizer, since the solved process of solid CF and uptake of inorganic elements (Markewich et al., 2012) by plant roots, which are easily affected by pattern of precipitation, could be skipped in foliar application (Dorahy et al., 2004). 


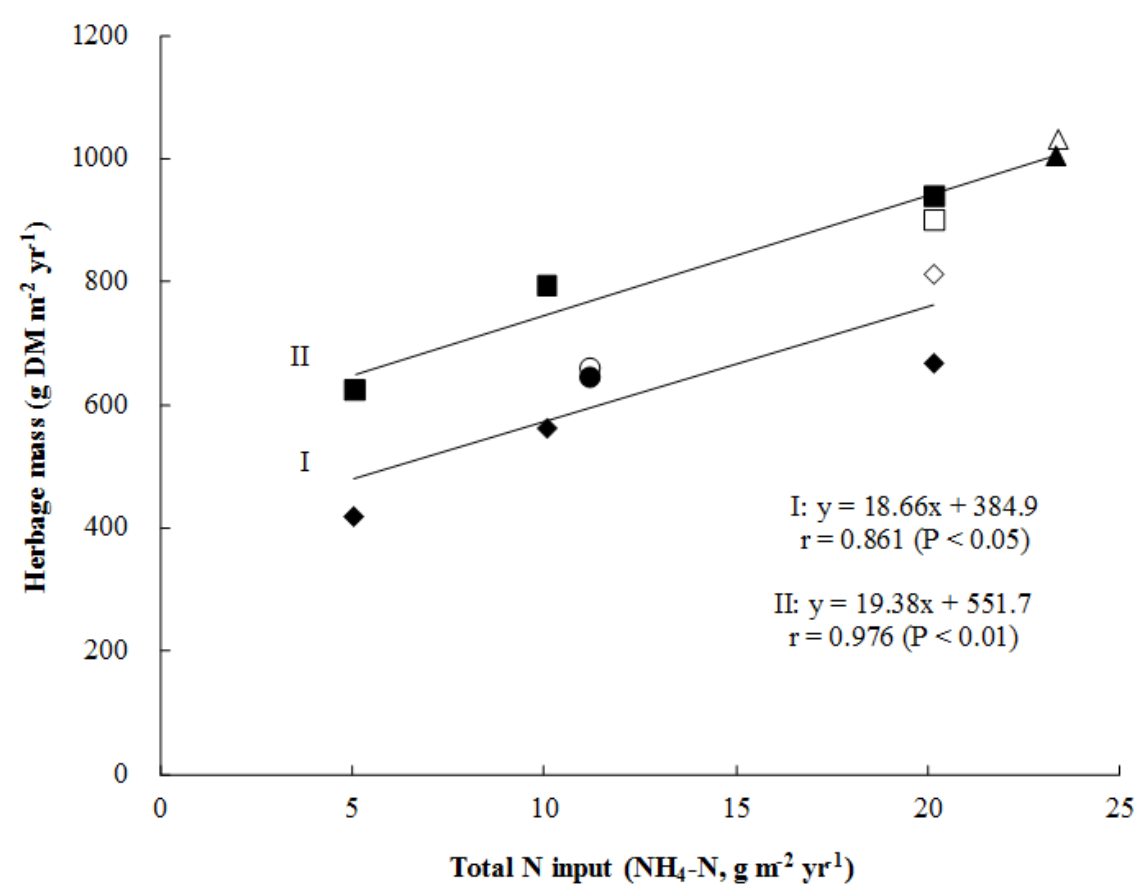

Fig. 7. Relationships between annual total of herbage mass and annul total of $\mathrm{N}$ input in Dwarf Napier grass in 2007 (I) and 2008 (II). (I) In 2007 under grazing management: CF (०), DE (•); under cut-and-carry management: CF $(\diamond)$, Low, medium and high levels of DE $(\diamond)$. (II) In 2008 under grazing management: CF $(\Delta)$, DE $(\boldsymbol{\Delta})$; under cut-and-carry management: CF ( $\square)$, Low, medium and high levels of DE (๘); Under cut-and-carry management, from Hasyim et al. (2014).

\section{Grazing Behavior of Dairy Cows on DL Napier} Grass Pasture

Grazing management aims to provide herbage in sufficient quantity and quality so as to satisfy animal needs under the sustaining pasture. During a grazing sequence, animals frequently face a choice between patches differing in vegetation structure and/or quality and cattle are shown to select the feed that provided the highest food intake rate (Distel et al., 1995) as well as in sheep (Kenney and Black, 1984) and goats (Illius et al., 1999), resulting in higher intake rate with higher quality and energy intake rate. Mukhtar et al. (2004) reported that plant height of DL Napier grass pasture decreased continuously with the grazing proceeded, suggesting that herbage consumption by grazing beef cows was more frequent in leaf blade than in leaf sheath and stem.

In many cases, plant growth reduction is less than expected from the proportion of biomass removed, which means that the vegetation could show a compensatory response to defoliation (Ferraro and Oestersheld, 2002). Wadi et al. (2004) reported that compensatory response in Napier grass and Pennisetum relatives to defoliation may be linked with plant environment (the decrease of self-shading), plant physiology (an increase of photosynthetic rate, the reallocation of growth from other parts of the plants, reduction of leaf senescence and greater light use efficiency) and morphogenetic adaptation (an activation and proliferation of axillary meristems, tillering and clonal development). Reducing pollution and intensive management for environmental purposes can be achieved by rotational grazing system on DL Napier grass pasture by dairy cows due to high percentage of leaf blade, dry matter yield and nutritive value. The most attractive aspect of time-controlled grazing systems to livestock producers is the increase in stocking rates (Heitschmidt et al., 1987; Jacobo et al., 2000), because of more intensive management resulting from the subdivision of large pastures and the addition of water sources (Hart et al., 1993). Difficulty in maintaining high stocking rates under continuous grazing for any extended period of time (Heitschmidt et al., 1983) has led to initial experiments to evaluate rotational grazing systems at stocking rates higher than those used in continuous grazing. However, maximization of livestock production requires maintaining high stocking rates because this variable determines the potential magnitude of profits realized by a ranching enterprise (Conner, 1991). We assessed that it is possible to achieve a sustainable utilization and longevity of DL Napier grass with rotational grazing of dairy cows. A remarkable feature of this grazing system is its flexibility, based on the understanding of the biological processes involved and rest periods varied throughout the seasons depending on the regrowth rate of the DL Napier grass. Later on, 
the present study could be applied into individual farms in one of the organic farming (Yadav et al., 2013) because the paddock scale experiment has been carried out for 2 years.

\section{Conclusion}

In conclusions, plant growth attributes, herbage mass, consumption and dry matter intake were comparatively similar between DE and chemical fertilizer plots for 2 years of grazing trials by dairy cows. Thus, DE can be utilized as a rapidly effective fertilizer on DL Napier grass pasture by rotational grazing system of dairy cows whose dry matter intake averaged $4.4 \mathrm{~kg} \mathrm{DM}$ head $^{-1}$ day $^{-1}$ across 4 grazing cycles both years in the hottest summer season from July to October in southern Kyushu, warm regions of Japan.

\section{Acknowledgement}

Authors would like to express sincere gratitude to Mrs. T. Yuge, N. Honda and K. Mitsutomi for the operation of liquid DE spray at Sumiyoshi Field in University of Miyazaki and the financial support to A. Wadi by JSPS in the fiscal year of 2006-2007.

\section{Author's Contributions}

Hadijah Hasyim: Participated in all experiments, coordinated the data analysis and contributed to the manuscript writing.

Ahmad Wadi: Participated in all experiments, coordinated the data analysis and contributed to the manuscript writing.

Yasuyuki Ishii: Designed the research plan, participated in the grazing experiment and contributed to the manuscript writing.

Sachiko Idota: Designed the research plan, participated in the chemical analysis and contributed to the manuscript writing.

Kiichi Fukuyama: Participated in the DE application and grazing experiment and organized the study.

\section{Ethics}

It is declared that there are no ethical issues that may arise in the present study.

\section{References}

Conner, J.R., 1991. Social and Economic Influences on Grazing Management. In: Grazing Management: An Ecological Perspective, Heitschmidt, R.K. and J.W. Stuth (Eds.), Timber Press, Portland, pp: 191-199.
Cu, T.T.T., T.X. Nguyen, J.M. Triolo, L. Pedersen and V.D. Le et al., 2015. Biogas production from Vietnamese animal manure, plant residues and organic waste: Influence of biomass composition on methane yield. Asian-Australas. J. Anim. Sci., 28: 280-289. DOI: 10.5713/ajas.14.0312

Distel, R.A., E.A. Laca, T.G. Griggs and M.W. Demment, 1995. Patch selection by cattle: Maximization of intake rate in horizontally heterogeneous pastures. Applied Anim. Behav. Sci., 45: 11-21. DOI: 10.1016/0168-1591(95)00593-H

Dorahy, C., G. Harper and P. Marczan, 2004. Using nutrient budgeting and environmental monitoring to assess the sustainability of effluent reuse from piggeries in New South Wales, Australia. Proceedings of the 3rd Australian New Zealand Soils Conference, Dec. 5-9, University of Sydney, Australia, pp: 1-8.

Ferraro, D.O. and M. Oesterheld, 2002. Effect of defoliation on grass growth. A quantitative review. Oikos, 98: 125-133. DOI: $10.1034 / \mathrm{j} .1600-0706.2002 .980113 . x$

Hanna, W.W., W.G. Monson and G.M. Hill, 1993. Evaluation of dwarf napiergrass. Proceeding of the 17th International Grassland Congress, (IGC' 93), Palmerston North, New Zealand, pp: 402-403.

Hart, R.H., J. Bissio, M.J. Samuel and J.W. Waggoner, Jr., 1993. Grazing systems, pasture size and cattle grazing behavior, distribution and gains. J. Range Manage., 46: 81-87. DOI: 10.2307/4002452

Hasyim, H., Y. Ishii, S. Idota, A. Wadi and Y. Sugimoto, 2009. Sustainable and environmentally conservative cropping system of dwarf Napiergrass and Italian ryegrass in southern Kyushu, Japan.(In) New paradigm for diversity of forage production in the East Asian region. Proceeding of the 3rd KoreaChina-Japan Symposium on Grassland Agriculture and Livestock Production, (ALP' 09), Seoul, Korea, pp: 60-61.

Hasyim, H., Y. Ishii, A. Wadi, S. Idota and Y. Sugimoto, 2010. Growth response of dwarf napiergrass to manure application originated from digested effluent. J. Warm Regional Society Anim. Sci. Japan, 53: 115-126. DOI: 10.11461/jwaras.53.115

Hasyim, H., Y. Ishii, A. Wadi and S. Idota, 2014. Effect of digested effluent of manure on soil nutrient content and production of dwarf Napier grass in southern Kyushu, Japan. J. Agron., 13: 1-11. DOI: $10.3923 /$ ja.2014.1.11

Heitschmidt, R.K., A.B. Johnson, J.R. Frasure and D.L. Price, 1983. Cow-calf and vegetation response to heavy rates of stocking at the Texas Experimental Ranch. Texas Agricultural Experiment Station Bulletin. 
Heitschmidt, R.K., S.L. Dowhower and J.W. Walker, 1987. Some effects of a rotational grazing treatment on quantity and quality of available forage and amount of ground litter. J. Range Manage., 40: 318-321. DOI: $10.2307 / 3898728$

Illius, A.W., I.J. Gordon, D.A. Elston and J.D. Milne, 1999. Diet selection in goats: A test of intake-rate maximization. Ecology, 80: 1008-1018.

DOI: $10.2307 / 177034$

Ishii, Y., M. Mukhtar, S. Idota and K. Fukuyama, 2005. Rotational grazing system for beef cows on dwarf napiergrass pasture oversown with Italian ryegrass for 2 years after establishment. Grassland Sci., 51: 223-234.

Ishii, Y., K. Hamano, D.J. Kang, K. Rengsirikul and S. Idota et al., 2013. $\mathrm{C}_{4}$-Napier grass cultivation for cadmium phytoremediation activity and organic livestock farming in Kyushu, Japan. J. Agric. Science Technol. A, 3: 321-330.

Jacobo, E.J., A.M. Rodriguez, J.L. Rossi, L.P. Salgado and V.A. Deregibus, 2000. Rotational stocking and production of Italian ryegrass on Argentinean rangelands. J. Range Manage., 53: 483-488. DOI: $10.2307 / 4003648$

Kenney, P.A. and J.L. Black, 1984. Factors affecting diet selection by sheep. 1. Potential intake rate and acceptability of feed. Aust. J. Agric. Res., 35: 551-563. DOI: 10.1071/AR9840551

Krysl, L.J. and B.W. Hess, 1993. Influence of supplementation on behavior of grazing cattle. J. Anim. Sci., 71: 2546-2555. PMID: 8407667

Markewich, H.A., A.N. Pell, D.M. Mbugua, D.J.R. Cherney and H.M. Van Es et al., 2012. The effects of some external management factors on the nitrogen composition of cattle manure on smallholder farms. Int. J. Agron., 2012: 437354-437364. DOI: $10.1155 / 2012 / 437354$

Marsh, R. and R.C. Campling, 1970. Fouling of pastures by dung. Herbage Abs., 40: 123-130.

Marten, G.C. and J.D. Donker, 1964. Selective grazing induced by animal excreta. I. Evidence of occurrence and superficial remedy. J. Dairy Sci., 47: 773-776. DOI: 10.3168/jds.S0022-0302(64)88762-2

McGilloway, D.A., A. Cushnahan, A.S. Laidlaw, C.S. Mayne and D.J. Kilpatrick, 1999. The relationship between level of sward height reduction in a rotationally grazed sward and short-term intake rates of dairy cows. Grass Forage Sci., 54: 116-126. DOI: 10.1046/j.1365-2494.1999.00158.x

MAFF, 2011. Statistics of agriculture, forestry and fisheries. Ministry of Agriculture, Forestry and Fisheries.

Minson, D.J., 1990. Forage in Ruminant Nutrition. 1st Edn., Academic Press, San Diego, ISBN-10: 0124983103, pp: 483.
Mukhtar, M., Y. Ishii, S. Idota, Y. Horii and T. Sonoda, 2004. Grazing characteristics in the dwarf napiergrass (Pennisetum purpureum Schumach) pasture by breeding beef cows at the first and second years after establishment. Grassl. Sci., 50: 121-131.

Savory, A. and S. D. Parsons, 1980. The savory grazing method. Rangelands 2: 234-237.

Schröder, J.J., A.G. Jansen and G.J. Hilhorst, 2005. Longterm nitrogen supply from cattle slurry. Soil Use Manage., 21: 196-204. DOI: 10.1111/j.1475-2743.2005.tb00125.x

Sollenberger, L.E., G.M. Prine, W.R. Ocumpaugh, W.W. Hanna and C.S. Jones Jr et al., 1988. Mott' dwarf elephantgrass: A high quality forage for the subtropics and tropics. Circular S-356, Agricultural Experiment Station, Institute of Food and Agricultural Sciences, University of Florida, Gainesville.

Tudsri, S., S.T. Jorgensen, P. Riddach and A. Pookpakdi, 2002. Effect of cutting height and dry season closing date on yield and quality of five Napier grass cultivars in Thailand. Trop. Grassl., 36: 248-252.

Thy, S. and P. Buntha, 2005. Evaluation of fertilizer of fresh solid manure, composted manure or biodigester effluent for growing Chinese cabbage (Brassica pekinensis). Livestock Res. Rural Dev.

Utamy, R.F., Y. Ishii, S. Idota, N. Harada and K. Fukuyama, 2011. Adaptability of dwarf napiergrass under cut-and-carry and grazing systems for smallholder beef farmers in southern Kyushu, Japan. J. Warm Regional Society Anim. Sci. Japan, 54: 87-98. DOI: $10.11461 /$ jwaras.54.87

Wadi, A., Y. Ishii and S. Idota, 2004. Effects of cutting interval and cutting height on dry matter yield and overwintering ability at the established year in Pennisetum species. Plant Prod. Sci., 7: 88-96. DOI: $10.1626 /$ pps.7.88

Williams, M.J. and W.W. Hanna, 1995. Performance and nutritive quality of dwarf and semi-dwarf elephantgrass genotypes in the south-eastern USA. Trop. Grassl., 29: 122-127.

Yadav, S.K., S. Babu, M.K. Yadav, K. Singh and G.S. Yadav et al., 2013. A review of organic farming for sustainable agriculture in northern India. Int. J. Agron., 2013: 718145-718152. DOI: $10.1155 / 2013 / 718145$ 